\title{
Jakub Orzeszek: Schulz i żałoba. O drugim ciele pisarza
}

\section{Etyka nekrograficzna}

Mówienie o śmi e r ci u S ch ul z a - o śmierci, która będzie „raczej insynuowana niż reprezentowana"1 ${ }^{1} \mathrm{w}$ jego twórczości - to coś zupełnie innego niż mówienie o śm i e r c i S ch ulz a. Ta pierwsza jest na różne sposoby sugerowana, zapośredniczona w metaforach lub emocjonalnej aurze fragmentu i odsłania się w mniej czy bardziej „hipnagogicznych, pozbawionych obrazu halucynacjach”2. Jej domeną jest estetyka. Dyskurs o niej bezustannie balansuje na granicy milczenia, ale niekiedy można na moment - jak mi się wydaje - uchwycić wrażenie jej obecności za pomocą literatury i sztuki (choć nie wiem, czy istnieją ogólne „zasady estetyki śmierci”, o których inspirująco pisał Michel Guiomar). Ta druga śmierć uderza bezpośrednio w ciało. Dotyka konkretnego losu, ma datę w kalendarzu, staje się tu i teraz. Jej dosłowna, nieodwracalna faktyczność, a także cielesność, materialność, w znacznie większej mierze przenoszą mówiącego w obszar etyki - sprawiają, że łatwiej osunąć się poza miarę stosowności, w zawłaszczającą przemoc języka lub „obsceniczność rozumienia”, ${ }^{3}$ w tekstualne podporządkowanie zmarłego. Ta śmierć obarcza innego rodzaju odpowiedzialnością za słowa.

Pierwsza jest niewyrażalna jako i d e a i dlatego stanowi - a przynajmniej może stanowić - szczególne wyzwanie dla stylu i wyobraźni. Druga jest niewyrażalna jako anihilujące $\mathrm{z}$ d a r z e n i e, które niszczy odniesienia do sensu, "gwałci ideę"4 i domaga się od mówiącego powściągliwości, bo przecież to nie doświadczenia lekturowe czy ambicje intelektualne są w mówieniu o niej ważne.

1 W ten sposób próbowałem zbliżyć się do tematu w szkicu Śmierć (3). Antyhasło do "Słownika schulzowskiego", "Schulz/Forum" 10, 2017, s. 85-111. Niniejszy tekst jest rozszerzoną wersją referatu, zaprezentowanego 17 listopada 2018 roku podczas III Dni schulzowskich w Gdańsku. Nie byłoby go w takiej formie, gdyby nie dyskusja i cenne uwagi Jerzego Kandziory, Urszuli Makowskiej, Małgorzaty Ogonowskiej, Józefa Olejniczaka, Hanele Palkovej i Stanisława Rośka, za które dziękuję.

2 M. Guiomar, Zasady estetyki śmierci, przeł. T. Swoboda, w: Wymiary śmierci, wybór i oprac. S. Rosiek, Gdańsk 2010, s. 82.

3 Zob. C. Lanzmann, The Obscenity of Understanding. An Evening with Claude Lanzmann, w: Trauma. Explorations in Memory, ed. C. Caruth, Baltimore 1995, zwłaszcza s. 201-209.

4 Określenie Stanisława Cichowicza: Śmierć: gwałt na idei lub reakcja życia, w: Antropologia śmierci. Myśli francuska, wybrali i przeł. S. Cichowicz, J. M. Godzimirski, Warszawa 1993. 
Teraz będzie mnie zajmować właśnie ta druga. Zapytam, w jakim stopniu seria tragicznych zdarzeń negatywnych - śmierć Schulza w Holokauście i zagłada jego ciała - odcisnęła się na recepcji pisarza. Nie tyle na odczytaniach jego twórczości (choć oczywiście też ${ }^{5}$ ), ile zwłaszcza na legendzie pośmiertnej, której elementy wciąż powracają - z mocą niemal paradygmatyczną - $\mathrm{w}$ dyskursach biograficznych o Schulzu i w literacko-artystycznych nawiązaniach do jego życia i dzieła. Mam przy tym świadomość niebezpieczeństw: uniwersalizacji, banalizacji, odrealnienia, „świętoszkowatej gadaniny"6, jakie wiążą się z tak sformułowanym tematem. I bynajmniej nie jestem pewien, czy opowiadając o śmierci Schulza w ramach akademickiego spotkania, nie popełniam mimowolnie jednego z tych przekroczeń, uznawanych w badaniach nad Zagładą za etycznie dyskwalifikujące. Rzecz jasna, moja intencja była inna.

Uważam, że krytyczny namysł nad modelami upamiętniania Schulza, a także nad specyficznymi stylami narracji ugruntowanymi w schulzologii, nie tylko nie musi prowadzić do indyferentyzmu, ale jest potrzebny - choćby do tego, by zrozumieć, jak bardzo schulzologia, od samego początku, naznaczona była nieprzepracowaną żałobą. Zarówno żałobą po Holokauście, jak i osobistymi żałobami Jerzego Ficowskiego i jego korespondentów - żałobami rozpisanymi w listach, które słali do niego po wojnie świadkowie życia Schulza. To właśnie ta korespondencja określiła treściową i, co równie istotne, retoryczną formę Regionów wielkiej herezji ${ }^{7}$.

Przyznaję, że odczuwam pewien dyskomfort związany z nadreprezentacją tego modelu, dzisiaj używanego niekiedy - jak mi się wydaje - z przesadą, która przemienia postać Schulza i jego biografię w przedmiot żałobnego kultu. Inaczej niż Janusz Rudnicki, nie chcę jednak prowokować ani palić mostów. Jego dwa szkice z cyklu Listy z Hamburga (odcinek siódmy i ósmy), publikowane w „Twórczości”

5 Zob. J. Olejniczak, Dyskurs Zagłady-przed ipo... (Wittlin, Wat, Schulz), w: idem, Pryncypia i marginesy Schulza, Gdańsk 2019, gdzie autor pisze, że „nasilenie «dyskursu Zagłady» i coraz bardziej «kłączasta» struktura wielkiej narracji o Zagładzie spowodowały, że także międzywojenne teksty [...] Schulza - choć nie tylko one - zostały przez ów dyskurs «wchłonięte», zaczęły współtworzyć tę wielką opowieść" (s. 138); oraz idem, Powroty w śmierć, Katowice 2009, s. 45-83.

6 T.W. Adorno, Dialektyka negatywna, przeł. K. Krzemieniowa, przy współpracy S. Krzemienia-Ojaka, Warszawa 1986, s. 507. Na temat etyki naukowego i literackiego pisania o Holokauście, problemu fundamentalnego w studiach nad Zagładą, zob. m.in.: J. Leociak, Tekst wobec Zagłady. O relacjach z getta warszawskiego, Toruń 2016; idem, Doświadczenia graniczne. Studia o dwudziestowiecznych formach reprezentacji, Warszawa 2009; A. Ubertowska, Holokaust. Auto(tanato)grafie, Warszawa 2014; eadem, Świadectwo, trauma, głos. Literackie reprezentacje Holokaustu, Kraków 2007; Reprezentacje Holokaustu, wybór i oprac. J. Jarniewicz, M. Szuster, Warszawa 2014; Stosowność i forma. Jak opowiadać o Zagładzie?, red. M. Głowiński, K. Chmielewska, K. Makaruk, A. Molisak, T. Żukowski, Kraków 2005; A. H. Rosenfeld, Podwójna śmierć. Rozważania o literaturze Holokaustu, przeł. B. Krawcowicz, Warszawa 2003.

7 Na temat retoryki Regionów wielkiej herezji i nie tylko: J. Kandziora, Poeta w labiryncie historii. Studia o pisarskich rolach Jerzego Ficowskiego, Gdańsk 2017. 
w 1992 roku - w kontekście setnej rocznicy urodzin i pięćdziesiątej rocznicy śmierci Schulza - były jawnie skierowane przeciwko „sakralnemu”8 aspektowi pisarstwa Ficowskiego. Atakowały „hagiograficzną” opowieść o egzekucji Schulza, parodiując ją w sposób śmiały, ale też utylitarny, brutalny, może nawet efekciarski. Moja propozycja jest inna i - mam nadzieję - sytuuje się poza tymi antagonizmami. Nie zapominając o nich ani o trudnych emocjach, jakie są w nie wpisane, spróbuję spojrzeć na zarysowaną tu tematykę w perspektywie tanatologii czy nekrohumanistyki. Celem tego przesunięcia, zarówno metodologicznego, jak i językowego, jest rozpoznanie i nazwanie kilku węzłów problemowych, wobec których będzie musiała się ustosunkować przyszła nekrografia Schulza.

A nekrografia taka z pewnością powinna kiedyś powstać. Kto wie czy nie powinna powstawać już teraz, równolegle z biografią autora Sklepów cynamonowych, jako jej dopełnienie, bo „dopiero obydwie łącznie obejmują całość [...] pośmiertnej egzystencji"9. Aby stało się to możliwe, przede wszystkim trzeba jednak zrekonstruować teks t k o ń c a bi o grafi i Schulza. To on „rozsadza ramy biograficznego dyskursu" $10 \mathrm{i}$ stanowi zarazem pierwszy punkt odniesienia dla wszelkich narracji nekrograficznych.

\section{9 listopada 1942, przed 12.00}

Informacje na temat śmierci Schulza zachowały się dzięki relacjom świadków i opowieściom osób postronnych. Są to jednak nierzadko wspomnienia wobec siebie sprzeczne, spisywane po latach, w obliczu zawodnej pamięci lub przeciwnie - głęboko emocjonalne, dotknięte traumą utraty albo martyrologiczne. Dzisiaj zresztą są już często nieweryfikowalne.

Najpełniejsza próba scalenia tego wielogłosu została przedstawiona przez Jerzego Ficowskiego w trzech tekstach ${ }^{\mathbf{1 1}}$, opublikowanych w ciągu trzydziestolecia 1956-1986. Nie jest ona przy tym wolna od osobistego konceptu pisarskiego i związanych z nim zabiegów literackich, na przykład uspójniania, selektywnego doboru treści, fabularyzowania. Krytyczna lektura źródeł, na których opierał się Ficowski, pokazuje raczej migotliwość tego przekazu. Niewykluczone więc, że tu

8 Stosunek Rudnickiego do stylu Ficowskiego najlepiej ilustruje metafora drzewa, którego gałęzie uginają się pod ciężarem gnijących owoców: „Za słodkie one są, mdłe i podejrzanie śliczne. Jedynym ratunkiem dla tego wyrosłego $z$ sakralnego podziwu drzewa byłby porządny kopniak. Z rozpędu, prosto w sam pień. Wszystko, co przekwitłe, spadłoby na dół, uwolnione od ciężaru patosu gałęzie powędrowałyby w górę". J. Rudnicki, List z Hamburga (8), "Twórczość" 1992, nr 10, s. 86.

9 S. Rosiek, Zwłoki Mickiewicza. Próba nekrografii poety, Gdańsk 1997, s. 110.

10 Ibidem, s. 108.

11 W artykule Przypomnienie Brunona Schulza („Życie Literackie” 1956, nr 6), w końcowym rozdziale Regionów (pierwsze wydanie 1967) i w szkicu Przygotowania do podróży z tomu Okolice sklepów cynamonowych (1986). Narrację tych trzech tekstów omówił Marcin Romanowski w artykule Śmierć Schulza, „Annales Universitatis Paedagogicae Cracoviensis. Studia Poetica” 2016, nr 4, s. 82-101. 
właśnie - w chaosie dyskursów, w niesprawdzalnych, równoległych wariantach, a nie w literackim porządku narracji - odsłania się koszmar, ale i polifoniczna prawda tej śmierci.

Nie budzi wątpliwości data dzienna ani miejsce zdarzenia - Bruno Schulz został zastrzelony 19 listopada 1942 roku na skrzyżowaniu ulic Czackiego i Mickiewicza, naprzeciw Judenratu (około stu metrów od dawnego domu rodzinnego przy Rynku), w akcji mordowania Żydów, od której ów dzień drohobyczanie nazwali później „czarnym czwartkiem”. Szacuje się, że w drohobyckim getcie zginęło wtedy od stu' ${ }^{\mathbf{1 2}}$ (Michał Chajes) do dwustu trzydziestu ${ }^{\mathbf{1 3}}$ (Samuel Rothenberg) osób, a bezpośrednim pretekstem do operacji gestapo była awantura z poprzedniego dnia, w wyniku której żydowski aptekarz Kurtz-Reines, broniąc się przed aresztowaniem, zranił esesmana Karla Hübnera w palec. Wybuchła panika. Według ustaleń Ficowskiego napastnicy zaczęli bez ostrzeżenia strzelać do przechodniów, „wbiegali za uciekającymi do bram domów, zabijali kryjących się na klatkach schodowych i w mieszkaniach"14. Schulz znalazł się w pobliżu, prawdopodobnie szedł do Judenratu po to, aby zaopatrzyć się w jedzenie. Izydor Friedman (Tadeusz Lubowiecki), znajomy pisarza i świadek jego śmierci, wspomina: „Słabszego fizycznie Schulza dopadł gestapowiec Günther, przytrzymał go, po czym przyłożył Mu rewolwer do głowy i strzelił dwukrotnie"15.

Najczęściej uznaje się, że tożsamość mordercy jest pewna: SS-scharfürher Karl Günther pojawia się w wielu niezależnych relacjach, między innymi Emila Górskiego, Leopolda Lustiga, Alfreda Schreyera czy Abrahama Schwarza. Ponadto utrwalił się pogląd, że śmierć Schulza była rodzajem odwetu na innym gestapowcu, protektorze Schulza, Feliksie Landau, który przedtem zastrzelił protegowanego Günthera - dentystę Löwa (wersja Ficowskiego ${ }^{16}$ ) lub stolarza Hauptmana (wersja Lustiga, przytaczana przez Henryka Grynberga ${ }^{17}$ ). Günther miał się później publicznie chwalić przed Landauem: „Zastrzeliłem twojego Żyda!’18. Trzeba jednak powiedzieć, że istnieje jeszcze co najmniej jedna wersja,

12 List Michała Chajesa do Jerzego Ficowskiego z 18 czerwca 1948 roku znajduje się w archiwum Jerzego Ficowskiego w Bibliotece Narodowej (Korespondencja Jerzego Ficowskiego, tom 4: C, III 14533). Cyt. za: Bruno Schulz w oczach świadków. Listy, wspomnienia i relacje, oprac. J. Kandziora, Gdańsk [w druku].

13 S. Rothenberg, List o zagładzie Żydów w Drohobyczu, wstęp, opracowanie i przypisy E. Silberner, Londyn 1984, s. 13.

14 J. Ficowski, Regiony wielkiej herezji i okolice. Bruno Schulz i jego mitologia, Sejny 2002, s. 506.

15 List Tadeusza Lubowieckiego (Izydora Friedmana) do Jerzego Ficowskiego z 23 czerwca 1948 roku, "Schulz/Forum" 7, 2016, s. 207.

16 J. Ficowski, Regiony wielkiej herezji i okolice, s. 220.

17 H. Grynberg, Drohobycz, Drohobycz, Warszawa 1997, s. 35.

18 Requiem. Alfred Schreyer i Abraham Schwarz rozmawiają o śmierci Brunona Schulza, w: M. Kitowska-Łysiak, Schulzowskie marginalia, Lublin 2007, s. 146. Fatalne uwikłanie Schulza w rywalizację między gestapowcami, choć dzisiaj może się wydawać nieprawdopodobnie wręcz fabularyzowane, pojawia się w kilku niezależnych i wczesnych świadectwach. Po wojnie stało się jednym z najtrwal- 
która nie potwierdza tego rozpoznania. Znajduje się ona w protokołach relacji z Zagłady, spisanych przez ocalałych Żydów z Drohobycza w latach 1946, 1947 i 1958 w Historisches Institut in Jsrael w Hajfie. Wszyscy świadkowie - Chaim Patrych, Moses Marcus Wiedmann, Theodora Reifler i Josef Weissmann - twierdzą, że mordercą Schulza nie był Günther, lecz Friedrich Dengg, gestapowiec, którego nazwisko autor Regionów wielkiej herezji z jakiegoś powodu ignoruje, choć przecież posiadał te źródła w swoim archiwum ${ }^{19}$. Zeznania zawarte w protokołach dodają też kilka innych różnic do narracji, którą stworzył Ficowski. Podania te są jednak w paru szczegółach niespójne i może dlatego zostały uznane przez biografa za niewiarygodne.

Nie ma pewności co do godziny zdarzenia. Emil Górski, dawny uczeń, a potem przyjaciel Schulza, twierdzi, że zobaczył się z nim jeszcze przed południem, gdy ten odwiedził go w zakładzie pracy Gärtnerei przy ulicy świętego Jana. „Wiadomość o śmierci Schulza doszła do mnie bardzo szybko, może w godzinę po jego wyjściu ode mnie"20 - deklarował w 1982 roku, co oznaczałoby, że pisarz zginął około 11.00 lub 12.00. Polemizuje z tym inny uczestnik wydarzeń, Alfred Schreyer - popierany przez Abrahama Schwarza - według którego „dzika akcja” gestapo rozpoczęła się zdecydowanie wcześniej, na pewno przed 9.00, a Schulz mógł zostać zamordowany „nawet przed godziną ósmą”21. Podobną chronologię odnajduję w pamiętniku Adeli Hilzenrad, prowadzonym od czerwca 1941 do sierpnia 1944 roku. Autorka, która w dniu śmierci Schulza ukrywała się w Drohobyczu poza gettem, zapisała, że strzelanina trwała od około godziny 8.00 do 11.00 - a sprowokowali ją Günther i Landau ${ }^{22}$.

szych składników legendy pośmiertnej pisarza i jako „biografem” było niejednokrotnie przetwarzane zarówno w artystycznych, jak i historycznoliterackich interpretacjach jego życiorysu.

19 Nazwisko Dengga nie pojawia się u Ficowskiego ani razu. Zostaje on przywołany w rozmowie Alfreda Schreyera i Abrahama Schwarza, jednak w zgoła odmiennym kontekście, nie jako zabójca Schulza, lecz "dobry gestapowiec” i "protektor” Schwarza (Requiem, s. 145-147). U Budzyńskiego Dengg figuruje co prawda w spisie gestapowców z Drohobycza, ale również ten autor za mordercę Schulza bezsprzecznie uznaje Karla Günthera (W. Budzyński, Miasto Schulza, Warszawa 2005, s. 416). Archiwa w Yad Vashem zawierają akt oskarżenia Dengga i pozostałych gestapowców z Drohobycza o „mordowanie ludności w okrutny sposób” i organizowanie „akcji na Żydów”, ale bez wskazania na 19 listopada 1942 roku. Zob. Yad Vashem Documents Archive, M.9 - Jewish Historical Documentation Center, Linz (Simon Wiesenthal Collection), File Numbers: 46, 812, https:// documents.yadvashem.org/index.html?language=en\&search=global\&strSearch=Friedrich $\% 20$ Dengg\&Gridltemld=3685799 (dostęp: 9.04.2019).

20 B. Schulz, Listy, fragmenty, wspomnienia o pisarzu, oprac. J. Ficowski, Kraków-Wrocław 1984, s. 75. Maszynopis szkicu, podpisany przez Emila Górskiego z datą: „listopad 1982”, znajduje się w archiwum Jerzego Ficowskiego w Bibliotece Narodowej (Korespondencja Jerzego Ficowskiego, tom 7: Goł - Gwa, III 14546). Cyt. za: Bruno Schulz w oczach świadków.

21 Requiem, s. 148.

22 United States Holocaust Memorial Museum's Collections, Hilzenrad family papers, Diary 1941-1944, Box 2 / Folder 1, Accession Number: 2011.278.1, https://collections.ushmm.org/search/catalog/ irn44069 (dostęp: 8.04.2019). 
Niejasne są także doniesienia na temat domniemanej ucieczki z Drohobycza, rzekomo planowanej przez Schulza na 19 listopada. Badacze raczej zgadzają się, że Schulz mógł wtedy posiadać fałszywe dokumenty aryjskie (Kennkarte) - pomóc w zorganizowaniu papierów miał ktoś $\mathrm{z}$ warszawskiego kręgu pisarza, może działacz podziemny Tadeusz Szturm de Sztrem ${ }^{\mathbf{2 3}}$ lub Zofia Nałkowska ${ }^{\mathbf{2 4}}$, a dostarczono je Schulzowi zapewne ze Lwowa za pośrednictwem Armii Krajowej25. Inną wersję podaje Harry Zeimer, dawny uczeń Schulza, według którego dokumenty zorganizował Schulzowi drohobycki znajomy związany z ruchem oporu, Tadeusz Wójtowicz ${ }^{26}$. Pisarz prawdopodobnie od kilku miesięcy planował podróż do Warszawy, o czym świadczyłyby na przykład starania, jakie podjął w 1942 roku, aby zabezpieczyć rękopisy i rysunki, oraz wspomnienia Zeimera, który na procesie Landaua zeznawał, że jakiś czas przed śmiercią („w ostatniej chwili”27) Schulz „zrezygnował ze wspólnej z nimi ucieczki”28. Ficowski wierzy Emilowi Górskiemu, który zapamiętał, że w dzień strzelaniny Schulz był gotów do drogi i odwiedził go właśnie po to, aby się pożegnać29. Z drugiej strony Izydor Friedman nie potwierdza tego przekonania. Przeciwnie, opisuje Schulza jako człowieka złamanego, pozbawionego nadziei na przetrwanie i woli życia, opóźniającego ucieczkę - niezdolnego do podjęcia jakiegokolwiek działania.

Ciało Schulza leżało na ulicy prawie dobę ${ }^{30}$. Jednak okoliczności samego pochówku pisarza pozostają niejasne. Jerzy Ficowski i Wiesław Budzyński za najbardziej prawdopodobne uznają świadectwo Friedmana, który w liście do

23 List Tadeusza Lubowieckiego do Jerzego Ficowskiego z 23 czerwca 1948 roku, s. 207.

24 J. Jarzębski, Schulz, Wrocław 1999, s. 85.

25 Mało wiarygodne wydają się za to opowieści Kazimierza Truchanowskiego, który wiele lat po wojnie utrzymywał, że jako leśnik w Spale był głównym inicjatorem i koordynatorem akcji ratunkowej Schulza. Zob. K. Truchanowski, Spotkania z Schulzem, w: Przymierzanie masek. W 100. rocznicę urodzin Kazimierza Truchanowskiego, pod red. Z. Chlewińskiego, Płock 2004, s. 30-31, a także krytyczny list Jerzego Ficowskiego, cytowany w artykule Jerzego Jarzębskiego Komentarz do komentarzy: Schulz edytorów, "Schulz/Forum” 3, 2013, s. 105-111.

26 A. Grupińska, Śmierć Brunona Schulza. O „czarnym czwartku” w Drohobyczu opowiada Harry Zeimer - uczeń i przyjaciel Schulza, "Życie” 2001, nr 98, s. 14. Przedruk rozmowy opublikowanej w „Czasie Kultury" 1990, nr 13-14.

27 Cyt. za: J. Ficowski, Regiony wielkiej herezji i okolice, s. 220.

28 Ibidem.

29 Radykalnie odmienny stosunek do ucieczki Schulza miał Artur Sandauer, który przez lata głosił tezę, że Schulz tego dnia nie tylko nie planował wyjazdu, ale wręcz szukał śmierci, a morderstwo Günthera było w istocie samobójstwem pisarza zadanym sobie cudzą ręką. Swoje poglądy na ten temat Sandauer budował jednak nie na podstawie świadectw, lecz własnej interpretacji twórczości Schulza, w której doszukiwał się przede wszystkim masochistycznego pędu do samozniszczenia, rozumianego bardzo dosłownie. Zob. A. Sandauer, O sytuacji pisarza polskiego pochodzenia żydowskiego w XX wieku, Warszawa 1982, s. 36-37, gdzie formułuje powyższe sądy w najbardziej bezpośrednim wariancie. Wypowiedzi Sandauera przyczyniły się do zaostrzenia sporu między nim a Ficowskim.

30 O czym świadczą dokładne, a przy tym w szczegółach zbieżne relacje, między innymi Ignacego Kriegela (H. Grynberg, Drohobycz, Drohobycz, s. 35), Abrahama Schwarza (Requiem, s. 149) czy Bohdana Odynaka, który opisuje scenę okradania zwłok Schulza z zegarka (ibidem, s. 150-151). 
Ficowskiego z 1948 roku deklaruje, że następnego ranka po strzelaninie pogrzebał Schulza na starym cmentarzu żydowskim w Drohobyczu ${ }^{31}$. Zgadzałoby się to ze wspomnieniami Abrahama Schwarza - jako członek grupy zbierającej zwłoki na rozkaz Niemców zapamiętał on, że martwego Schulza grabarze nie ruszali, bo „ktoś miał zaraz przyjść, poszedł tylko po wóz, którym chciał przewieźć ciało Schulza na stary cmentarz [i pochować obok jego matki - przyp. J. O.]"32. Innego zdania jest Jerzy Jarzębski. Badacz za wiarygodną uważa relację Leopolda Lustiga, który - jak twierdzi - także uczestniczył w „oczyszczaniu” getta z zabitych. Według niego zwłoki Schulza zostały przewiezione razem z innymi na nowy cmentarz żydowski i tam pogrzebane wspólnie z ciałem stolarza Hauptmana (protegowanego Günthera). Lustig przypomina sobie nawet miejsce: „Leżeli przy murze, od wejścia w prawo, i tam zakopaliśmy ich w jednym grobie"33. Istnieje jeszcze co najmniej jedna wersja tych zdarzeń, powtarzana przez Budzyńskiego za drohobycką polonistką Dorą Kacnelson, lecz z powodu braku podobnych głosów nie sposób ocenić jej wiarygodności. Kacnelson znała niejakiego Hauptmana (nie stolarza), który wiele lat po wojnie twierdził ponoć, że razem z pozostałymi pracownikami Judenratu pogrzebał ciało Schulza - prawie trzy dni (!) po strzelaninie - w zbiorowej mogile naprzeciw synagogi, obok starego cmentarza żydowskiego ${ }^{34}$.

Niezależnie jednak od tego, którą relację uznamy za prawdziwą, trzeba powiedzieć, że faktyczne miejsce pochówku Schulza pozostaje nieznane. Nie ma już starego cmentarza żydowskiego. Na jego terenie zbudowano w latach pięćdziesiątych blokowisko. Nowy cmentarz żydowski, obecnie zdewastowany, porastają dzika trawa i krzaki.

\section{Materialność metafory}

Negatywne metafory, za pomocą których dwudziestowieczna tanatologia konceptualizowała śmierć, takie jak „przerwanie”, „pęknięcie”, „pułapka niebytu”, „agresja zgnilizny”35, „objawienie bólu istnienia”36, „pustka, która wdziera się w pełnię życia"37, „godzina absurdu”, „skandal”38, stają się tu ordynarnie dosłowne. Są zarazem niedostateczne, mimo całej brutalności, jaką ewokują, nawet

31 List Tadeusza Lubowieckiego do Jerzego Ficowskiego z 23 czerwca 1948 roku, s. 207-208.

32 Requiem, s. 149.

33 H. Grynberg, op. cit., s. 36.

34 W. Budzyński, Schulz pod kluczem, Warszawa 2013, s. 16.

35 L.-V. Thomas, Trup. Od biologii do antropologii, przeł. K. Kocjan, Łódź 1991, s. 5.

36 M. Vovelle, Historia ludzi w zwierciadle śmierci, w: idem, Śmierć w cywilizacji Zachodu. Od roku 1300 po współczesność, przeł. T. Swoboda, M. Ochab, M. Sawiczewska-Lorkowka, D. Senczyszyn, Gdańsk 2008, s. 45.

37 V. Jankélévitch, Tajemnica śmierci i zjawisko śmierci, przeł. S. Cichowicz, J. M. Godzimirski, w: Antropologia śmierci, s. 45.

38 Ibidem, s. 59. 


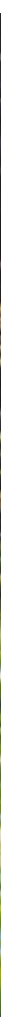


mimo niewątpliwych związków pomiędzy takim sposobem konceptualizowania śmierci a doświadczeniem „rzezi wielkich wojen”39 (Ariès pisze o doświadczeniu „śmierci plugawej”), w cieniu których formowała się pierwsza generacja tanatologów w Europie. Zagłada Schulza przekracza akt ulicznej egzekucji - dotyczy również pośmiertnego losu ciała, które jego mordercy skazali najpierw na uwłaczającą ekspozycję, a ostatecznie na anihilację w nieoznaczonym, zapewne masowym grobie. Ta być może najbardziej radykalna i nienawistna forma nekroprzemocy ${ }^{\mathbf{4 0}}$, jaką jest w obliczu tradycji żydowskiej, a także szeroko rozumianej kultury Zachodu, instrumentalne usunięcie ciała lub grobu, równoważne $\mathrm{z}$ intencją usunięcia śladu istnienia, nazywana jest przez badaczy Holokaustu jakby tautologicznie nekrobójstwem, nekrocydem ${ }^{41}$. Z abijanie martwego. Nie ma w tej tautologii nic metaforycznego, jest tępa groza tych praktyk.

\section{Schulz $\neq$ Mickiewicz}

„Materia - choćby jej strzęp, niewielka resztka, choćby garstka prochu - jest dla aktywności w dziejach nieodzowna. Dzięki niej umarli podtrzymują swoje więzi ze światem, wchodzą w nowe związki z żywymi, którzy - tak, prochom! - przyznają często niemałą suwerenność. Materialne resztki (zwłoki, trumna, grób, należące do umarłych rzeczy) zastępują ciało unicestwione przez śmierć"42. Autor tych słów i twórca gatunku nekrografii, Stanisław Rosiek, pisze dalej o „wielkiej przemianie” zmarłego, mając na myśli wiele praktyk symbolicznych, za pomocą których żywi starają się oswoić nieodwracalność rozdzielenia, a także przysłonić nicość, owo Bataille’owskie informe, w które obracają się zwłoki w procesie tanatomorfozy. Wielka przemiana prowadzi zatem do złagodzenia biologicznego i semiotycznego kryzysu, spowodowanego przez śmierć - „nagłą lukę w dyskursie"43. Trup, ów „poza-znaczący («outre-signifiant»)"44, jak nazywa go Louis-Vincent Thomas za Jeanem-Thierrym Maertensem, powraca do porządku dyskursu jako „miejsce konwergencji bardzo wielu fantazmatów”45.

39 P. Ariès, Człowiek i śmierć, przeł. E. Bąkowska, Warszawa 1992, s. 559.

40 Termin „nekroprzemoc” zapożyczam od amerykańskiego antropologa Jasona De Leóna. Według jego definicji jest to „przemoc dokonywana poprzez szczególne traktowanie zwłok, postrzegane przez sprawcę lub/i ofiarę (oraz grupy kulturowe, jakie reprezentują) jako uwłaczające, świętokradcze albo nieludzkie". J. De León, The Land of Open Graves. Living and Dying on the Migrant Trail, photo. by Michael Wells, Oakland 2015, s. 69. Zob. też J. Orzeszek, Nekroprzemoc? Polityka, kultura i umarli, „Twórczość” 2019, nr 5, s. 82-92.

41 E. Domańska, Nekros. Wprowadzenie do ontologii martwego ciała, Warszawa 2017, s. 191.

42 S. Rosiek, op. cit., s. 57.

43 L.-V. Thomas, op. cit., s. 52.

44 Ibidem.

45 lbidem, s. 51. 
Dokonuje się to w ramach dwóch powiązanych ze sobą procedur symbolicznych: „raz przez podwojenie zwłok, raz przez ich transformację"46, przez wyobrażenie i prze obrażeni e martwego ciała. Pierwsza praktyka polega na tworzeniu wizerunków, podobizn, reprezentacji zmarłego, utrwalających jego postać i n effi g i e. „Tworzy się dzięki nim coś w rodzaju bytu «drugiego», wtórego"47 - inne ciało-obraz, niepodatne na prawa biologicznego rozkładu, przeniesione w dziedzinę wyobraźni i wyobrażeń. „Effigie, zajmując miejsce śmiertelnych resztek umarłego, przejmuje jego funkcje, jego właściwości i jego godność" 48 . Drugie działanie obejmuje bezpośrednio materię, prowadzi do przekształcenia martwego ciała w p r z e d m i o t ż a ło b n y. Przemiana ta rozpoczyna się w chwili rytualnego przygotowania zwłok do ceremonii pogrzebowych, kończy zaś ukryciem ich w grobie i zastąpieniem ich materialnym signifiantem: nagrobkiem, pomnikiem, odlewem dłoni, maską pośmiertną. Kluczowa rola przypada właśnie grobowi, który - jak pisze francuski tanatolog Jean-Didier Urbain - „ukrywa zwłoki oraz ich nieuniknioną przyszłość fizyczno-chemiczną”. Jest „semiotycznym obliczem tego, co ukrywa [...] znakiem afirmacji, znakiem pozytywnym, albowiem - postrzegany fenomenologicznie (z punktu widzenia człowieka pogrążonego w żałobie) - pozwala przekonać się o jego pełnej i niezmiennej referencyjności, którą sygnalizuje samo jego istnienie, pozwala zmaterializować pewne iluzoryczne wyobrażenie, wywołuje efekt «somatyczności» lub przynajmniej takiej obecności, która uwalnia nas od pustki, od poczucia utraty, od bezsensu"49.

Zadanie nekrografa powinno polegać na śledzeniu zarówno materialnych, jak i symbolicznych dziejów martwego ciała, a także na krytycznym opisie „wielkiej przemiany” - procesu powtórnego budowania więzi między umarłym a żywymi. Dobrze widać jednak, że nekrografia Schulza musiałaby się zdecydowanie różnić od nekrografii Mickiewicza, która stała się tematem studiów i szkiców Stanisława Rośka. Istotnie, pośmiertne losy „Wielkiego Poety” i „Wielkiego Polaka” można by uznać za zwierciadło negatywne dla losów Schulza. Dzieli ich prawie wszystko. Nie tylko moment i okoliczności śmierci, lecz także modele egzystencji, które uosabiali. Biografia pierwszego już za jego życia miała charakter w najwyższym stopniu publiczny. Była to biografia „bohatera Polaków", a po jego śmierci w sposób naturalny stała się częścią zmitologizowanej i zideologizowanej „narracji narodu” (Homi Bhabha ${ }^{50}$ ). Nie

46 S. Rosiek, op. cit., s. 202.

47 Ibidem, s. 203.

48 Ibidem, s. 205.

49 J.-D. Urbain, W stronę historii Przedmiotu Funeralnego, przeł. M. L. Kalinowski, w: Wymiary śmierci, s. $322-323$

50 H. K. Bhabha, Miejsca kultury, przeł. T. Dobrogoszcz, Kraków 2010, s. 146. 
powinien dziwić heroiczno-patriotyczny kult, jakim otoczono szczątki Mickiewicza. Jego nekrograf dysponuje bogactwem faktów - zarówno materialnych, obejmujących dzieje zwłok, a potem przedmiotów żałobnych, relikwii, pamiątek, jak i symbolicznych, na które składają się aktywność dyskursywno-polityczna wokół trupa i jego reprezentacje.

Biografia Schulza - mimo że z całą pewnością nie była biografią „skromnego nauczyciela z Drohobycza" - miała charakter prywatny, podobnie jak jego twórczość, która nie mogła się wpisać w ideologie i oczekiwania narzucane jej przez Historię ${ }^{51}$ (inaczej niż twórczość Mickiewicza). W legendzie pośmiertnej otacza się Schulza, jako artystę - ofiarę Holokaustu, kultem martyrologicznym. W jego przypadku jednak ów proces „symbolicznego odzyskania” 52 został zatrzymany. Ciąży nad nim niedomknięte doświadczenie „dwuznacznej straty”53 - straty, która nie odnajduje oparcia w materii i która nie kończy się konsolacją. Nekrografia Schulza różniłaby się, także metodologicznie, od nekrografii Mickiewicza przede wszystkim dlatego - znacznie bardziej musiałaby się skupić na śledzeniu kolejnych reprezentacji zmarłego in effigie oraz na analizie dyskursu. Drugie ciało Schulza, ciało wyobrażone i opowiadane, istnieje nie obok, lecz $\mathrm{z}$ a $\mathrm{m}$ i a s t, w zastępstwie nieobecnego przedmiotu żałobnego.

\section{Śmierci (po śmierci)}

Znamienne, że Przypomnienie Brunona Schulza z 1956 roku Jerzy Ficowski rozpoczyna emocjonalnym, po części fabularyzowanym opisem śmierci pisarza. Nie tylko ten fragment, ale cały tekst, uchodzący za początek powojennej schulzologii, ma charakter jakby „spóźnionego nekrologu”54. Ta nekrologiczność stanowi zarazem klamrę domykającą dzieło Ficowskiego. Ostatnie wydanie Regionów wielkiej herezji z 2002 roku zostało opatrzone mottem, które pełni funkcję epitafium wiersz Mój nieocalony z tomu Ptak poza ptakiem, przedrukowany na pierwszej stronie tego wydania, jest jak liryczny nagrobek postawiony Schulzowi, ale i osobisty testament biografa, podsumowujący jego wieloletnie prace. Między tymi dwoma tekstami rozciąga się niemal pół wieku poszukiwań tego, co „ocalało na spalonej ziemi” ${ }^{55}$, choć było „skazane na zagładę"56 - wszelkich świadectw

51 Za co zaatakowali go na przykład Kazimierz Wyka i Stefan Napierski.

52 J.-T. Maertens, Nad otwartym grobem. Semiotyka zmarłego, przeł. M.L. Kalinowski, w: Wymiary śmierci, s. 267.

53 Zob. P. Boss, Ambiguous Loss. Learning to Live with Unresolved Grief, Cambridge-London 1999.

54 Tej efektownej, a przy tym - jak mi się wydaje - trafnej formuły użył Marcin Romanowski podczas konferencji na IV Dniach schulzowskich w Gdańsku w listopadzie 2019 roku.

55 J. Ficowski, Regiony wielkiej herezji i okolice, s. 194.

56 Idem, Wprowadzenie do „Księgi listów” do wydania z roku 2002, w: B. Schulz, Dzieła zebrane, t. 5: Księga listów, zebrał i przygotował do druku J. Ficowski, uzupełnił S. Danecki, Gdańsk 2016, s. 8-15. 
o Schulzu, a także jego rękopisów i „archiwum egzystencji”. W misję ratowniczą Ficowskiego wpisana była też działalność komemoratywna.

W 1989 roku na przykład, w związku z nadchodzącym stuleciem urodzin i pięćdziesięcioleciem śmierci Schulza, biograf próbował bezskutecznie doprowadzić do ufundowania w Warszawie symbolicznego nagrobka pisarza. Pomnik, zaprojektowany przez warszawskiego rzeźbiarza Marka Tomzę, miał się składać z dwóch macew, białej i czarnej, ustawionych naprzeciwko siebie. Na pierwszej miał się znajdować odwrócony ołowiany autograf Schulza, na drugiej - zwierciadło sferyczne z czarnego szkła, w którym odwiedzający przeglądaliby się na tle właściwego podpisu Schulza ${ }^{57}$.

Takich symbolicznych nagrobków i epitafiów stawiano jednak Schulzowi w XX wieku znacznie więcej - i nadal się stawia w wieku XXI. Elegia na tragiczną śmierć Schulza to chyba najczęstsza forma składania hommage autorowi Sklepów cynamonowych w literaturze, sztuce, teatrze, filmie czy muzyce. Systematyczny opis tych realizacji, krytyczna ich charakterystyka, od najbardziej stereotypowych przedstawień i scenariuszy (Schulz jako bezbronny Żyd uwikłany w rywalizację dwóch gestapowców) po te idiomatyczne (Schulz jako ryba odpływająca w Bałtyku) - to zadanie na osobne studium. Jak duże jest pole badawcze, pokazuje już kilka przykładów. Do najbardziej znanych i uznanych tekstów nekrologicznych należy z pewnością film Wojciecha Jerzego Hasa Sanatorium pod Klepsydra z 1973 roku. Scena końcowa - z katabazą Józefa, który opuszcza sanatorium, potykając się między niezliczonymi macewami i świecami - stanowi nawiązanie do Holokaustu i nadaje całości żałobny charakter. Nie tak jednoznaczna, lecz również niepozbawiona cech nekrologicznych jest rzeźba Mirosława Bałki z 1982 roku zatytułowana Bruno Schulz, w której można rozpoznać subtelne nawiązanie do formy maski pośmiertnej. Osobliwy (także dlatego, że balansujący na granicy kiczu), a dziś chyba zapomniany przykład literackiego nekrologu Schulza znajduje się w zbiorze eseistycznym Włodzimierza Paźniewskiego Życie i inne zajęcia, opublikowanym w tym samym roku. W szkicu Mesjasz na wakacjach w Truskawcu Paźniewski przedstawia ostatnie dni pisarza w konwencji pasji: Schulz ma u niego twarz Chrystusa, Landau jest Piłatem, Günther odgrywa rolę Judasza. Na drugim planie patosu dodaje zaginiona powieść Schulza Mesjasz - nieukończone dzieło Paźniewski przyrównuje do brutalnie przerwanego życiorysu autora ${ }^{\mathbf{5 8}}$.

Funeralno-elegijna tradycja nie słabnie także $\mathrm{w}$ najnowszych nawiązaniach do twórczości i życia autora Xięgi bałwochwalczej. Wprost przeciwnie. Potwierdza to literatura polska przełomu XX i XXI wieku, nie tylko Różewicz i jego wiersz

57 J. Ficowski, Pomnik Brunona Schulza, „Życie Warszawy” 1989, nr 14, https://schulzforum.pl/pl/kalendarz/7-lipca-1989 (dostęp: 21.12.2019). Zob. też dokumentację projektu Marka Tomzy, publikowaną w niniejszym numerze "Schulz/Forum".

58 W. Paźniewski, Życie i inne zajęcia, Warszawa 1982, s. 123-138. 
W świetle lamp filujących - przede wszystkim poezja roczników siedemdziesiątych. Dla autorek i autorów tego nurtu, nazywanego przez krytykę poezją „ośmielonej wyobraźni”, Schulz stał się zarówno literackim patronem, jak i „tekstem” - bohaterem ich wierszy, którego próbują na rozmaite sposoby wskrzeszać, mimo to jednak pojawiającym się zawsze w cieniu swojej śmierci (jak w wierszach Radosława Kobierskiego Drohobycz, Śliwice z roku 1999, Tomasza Różyckiego Zagłada wioski z 2006 czy Ewy Elżbiety Nowakowskiej Płachta śniegu lub Nauczyciel robót ręcznych z 2013). „Brak grobu Schulza, niemożność odnalezienia jego szczątków, mimo podejmowanych wysiłków, inspiruje poetów do ukazywania go jako ducha, zjawy, podobnego romantycznemu upiorowi lub wpisywania go w realia świata przedstawionego jego dzieł, na wzór zawartych w jego prozie projektów przedłużania życia ojcu - zamienionego w ptaka, robaka lub (bardziej innowacyjnie) jako niepozorny, choć wyróżniający się czymś szczególnym, przedmiotowy element otoczenia”59 - pisze Magdalena Rabizo-Birek. Lecz zarazem „Tej straty, tej żałoby, mimo upływu dziesiątków lat, nie udaje się przepracować"60.

Podobnie w recepcji artystycznej. Na obrazie Jana Szczepkowskiego z 2006 roku drohobycki pisarz został przedstawiony w pozycji płodowej, na pustej ulicy, z twarzą zasłoniętą dłońmi - ten rozpoznawalny gest tanatyczny został przełamany, choć w istocie tylko pozornie, bo efekt jest raczej odwrotny, gorzko ironicznym tytułem Bruno Schulz udaje, że nie żyje. Warto wspomnieć też o dwóch pracach powstałych w 2018 roku w ramach projektu Bruno Schulz. Artysta nienazwany, prowadzonego przez Fundację Republika Marzeń. Obie w sposób czytelny nawiązują do okoliczności śmierci Schulza. Pierwsza, autorstwa Pawła Althamera, zatytułowana Drzewo Schulz, jest metalową instalacją, której górna część, jakby ogołocona korona drzewa, przypomina sylwetkę przewróconego człowieka ponakłuwaną gwoździami-cierniami. Na nie z kolei nabito, zamiast liści, minirzeźby z mydła i fragmenty brązowej gąbki, która imituje kawałki chleba. Autorem drugiej pracy jest Jerzy Kalina. Jego $W$ niebo stąpanie, instalacja umieszczona pierwotnie w Muzeum Żydów Mazowieckich w Płocku, składa się z czternastu figur mężczyzn, kobiet i dzieci o naturalnych rozmiarach. Każda z figur, które razem stanowią alegorię ofiar Holokaustu, trzyma w ręku swoją macewę - zrobioną z chleba.

Wszystkie te prace i teksty realizują, jakby za Ficowskim, ocalający topos upamiętniania, uobecniania przedwcześnie zmarłego pisarza - ofiary Zagłady i nekrocydu. Na przekór intencjom oprawców starają się oddać mu hołd i przywrócić utraconą somatyczność. Jeśli spojrzeć na nie z perspektywy antropologa żałoby - uczestniczą w kulturowym procesie konsolacji. Zmierzają „ku

59 M. Rabizo-Birek, Schulz poetów "ośmielonej wyobraźni" (preliminaria), „Schulz/Forum” 13, 2019, s. 80

60 Ibidem, s. 84. Ciekawego materiału dostarcza pod tym względem także 4 tom z serii „Acta Schulziana" z 2019 roku, zatytułowany Bruno Schulz w poezji. Antologia otwarta. 


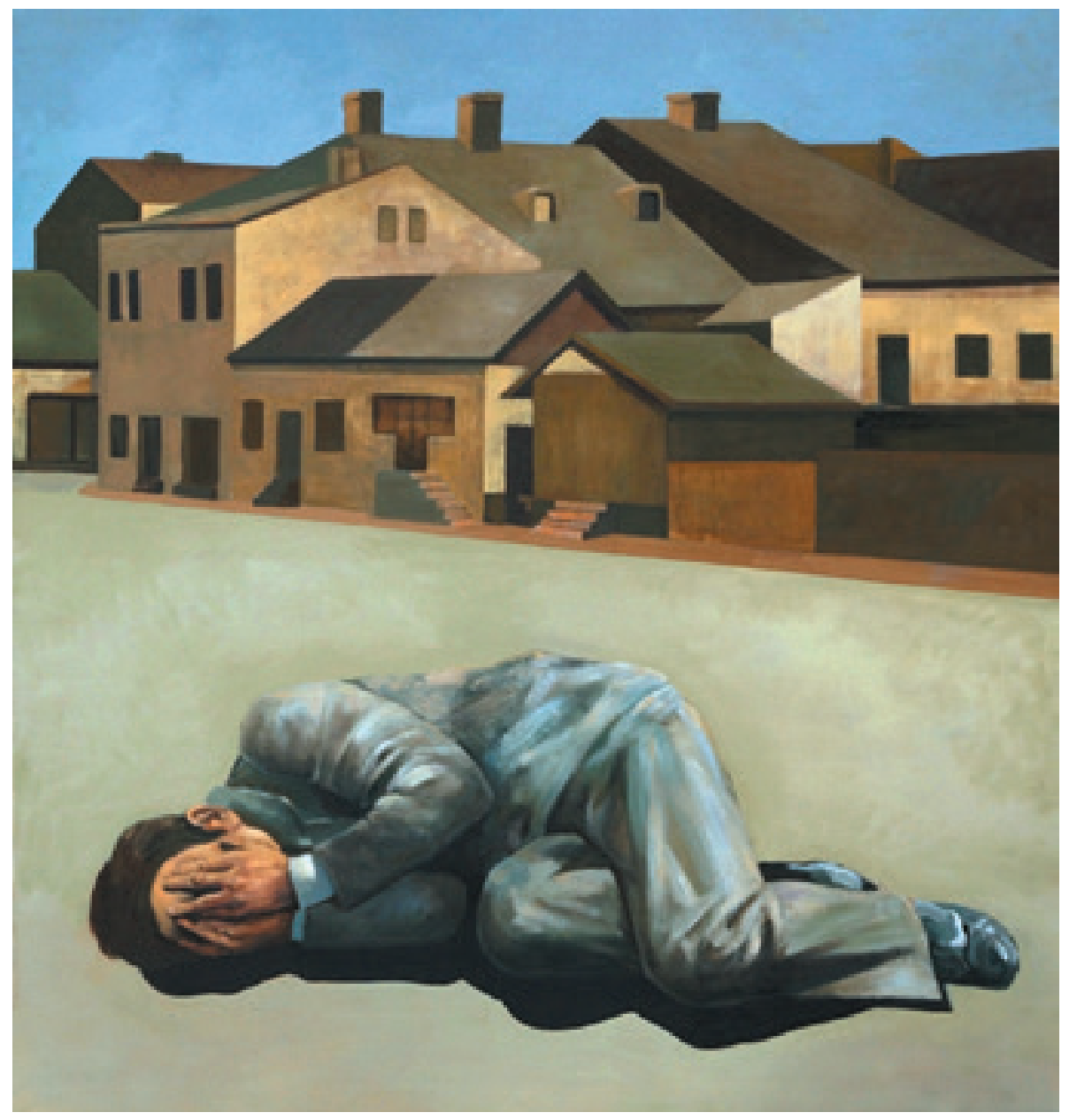


stworzeniu swego rodzaju zrytualizowanego kodu, stanowiącego ujście dla chaosu i nieładu, dzięki czemu agresywny ładunek zostaje zneutralizowany, a autodestruktywna rzeczywistość zastąpiona symbolem"61.

Zatem śmierć Schulza jako symbol? Na ten normatywizujący efekt narracji funeralnych i martyrologicznych o Schulzu zwracał uwagę Jerzy Jarzębski, jednocześnie dostrzegając związane z nimi - wbrew zamiarom ich twórców - niebezpieczeństwo redukcjonizmu. „W tym momencie twórczość Schulza zrasta się na dobre z legendą biograficzną pisarza, [...] znika też Schulz jako człowiek uniwersalny, pozostaje udręczony Żyd czekający na śmierć”. I dalej: „Schulz odgrywał w życiu obydwie te role, ale - paradoksalnie - to ta druga przesądziła w większym stopniu o jego międzynarodowej sławie. Jako artysta i myśliciel drohobycki twórca stawia swoim odbiorcom znacznie wyższe wymagania, żąda dla siebie nie tylko uwagi w lekturze i inteligencji pozwalającej kojarzyć i odczytywać różne systemy znaków, ale też erudycji pozwalającej włączać w procesie odbioru rozmaite konteksty literackie i kulturowe. Jako Żyd skazany przez nazistowski system na śmierć i usiłujący, dzięki swym talentom malarskim, odwlec nieuchronną egzekucję wymaga głównie empatii”"62.

W podobnie sceptycznym tonie pisze Norman Ravvin, analizując pośmiertną obecność Schulza w literaturze międzynarodowej, między innymi w powieściach Mesjasz ze Sztokholmu Cynthii Ozick, Patrz pod: Miłość Davida Grossmana oraz Praska orgia Philipa Rotha. Ravvin stwierdza, że poza granicami Polski i poza zasięgiem języka polskiego „ikoniczność Schulza [...] jest w dużej mierze spowodowana okropnymi okolicznościami jego śmierci, która ma status paradygmatycznego aktu przemocy Niemców wobec Żydów w okupowanej Europie Wschodniej"63. Twarz Schulza - pisze Ravvin - stała się emblematem Zagłady, niezależnie od tego, że najczęściej reprodukowany jest jego autoportret z cliché-verre'u Dedykacja, datowanego na mniej więcej 1920 rok (zresztą nie zachował się żaden autoportret artysty z okresu po roku 1939).

W imaginarium Zachodu Schulz odgrywa po śmierci rolę jakby odwrotną do roli Anne Frank. Podczas gdy ona „została przeobrażona w postać świetlanej, młodej świętej Holokaustu, w upostaciowienie dziecięcego pragnienia życia nawet $\mathrm{w}$ obliczu potwornych zdarzeń, w łaskawą zapowiedź powrotu normalności po Holokauście”, Bruno Schulz jako przeciwsymbol tego pocieszenia „musi

61 A.M. di Nola, Tryumf śmierci. Antropologia żałoby, przeł. M. Woźniak, R. Sosnowski, J. Kornecka, M. Surma-Gawłowska, M. Olszańska, Kraków 2006, s. 188.

62 J. Jarzębski, Sklepy bławatne i sklepy cynamonowe, w: B. Schulz, Dzieła zebrane, t. 2: Sklepy cynamonowe, wstęp i oprac. J. Jarzębski, dodatek krytyczny S. Rosiek, oprac. językowe M. Ogonowska, Gdańsk 2019, s. 17.

63 N. Ravvin, Veneration and Desecration: The Afterlife of Bruno Schulz, w: Bruno Schulz: New Readings, New Meanings / Nouvelles lectures, nouvelles significations, published under the direction of / publié sous la direction de S. Latek, Montreal-Cracow 2009, s. 61. Tłumaczenie moje - J. O. 


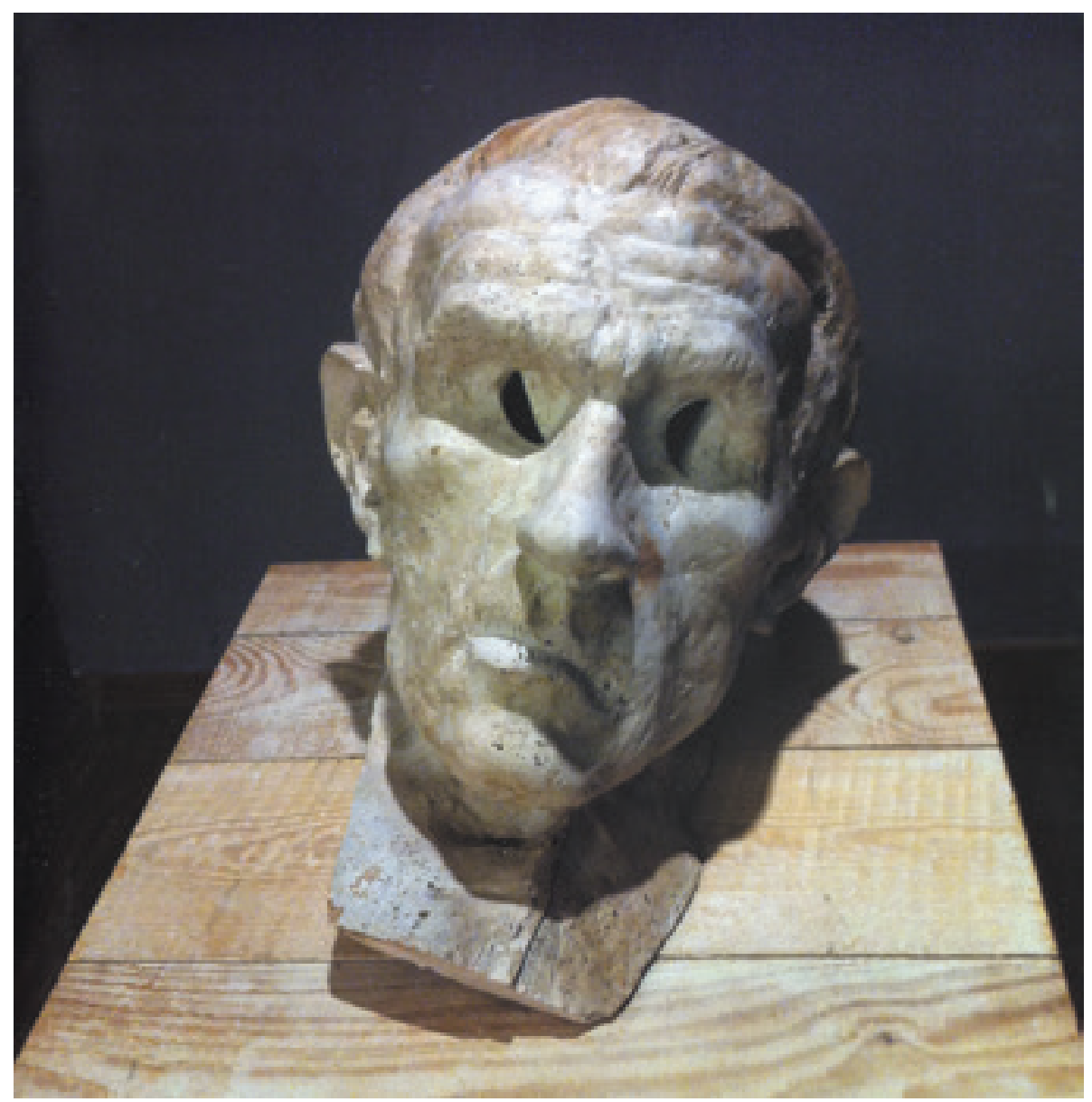

Mirosław Bałka, Bruno Schulz, 1982,

fotografia Janusza Foglera 
umierać, wciąż i wciąż, od kuli mordercy na ulicy Drohobycza. W kolejnych szkicach krytycznych, na kolejnych obwolutach książek, w kolejnych utworach autorów, którzy aspirują do miana jego akolitów, przywołuje się go po to, by s t a 1 się swoją śmiercią"64.

Trudno się nie zgodzić, przynajmniej do pewnego stopnia, $\mathrm{z}$ obawami Ravvina. Zatrzymany w rytuale tanatycznym, Schulz przypomina jedną z tych smutnych figur woskowych, których egzystencję podtrzymuje „nałóg reprezentowania”. „Każdemu z nich wisiał z ust, już martwy, jak język uduszonego, ich krzyk ostatni"65. Czytam ten fragment Wiosny i nagle uderza mnie inne sformułowanie - nałóg reprezentowania żałoby.

\section{Drugie ciało pisarza}

Nie miałem jednak racji, gdy pisałem, że nekrograf Schulza musi ograniczać się do effigies. Materialna historia jego ciała nie została przerwana w listopadzie 1942 roku. Ciałem pośmiertnym, które istnieje ponad utraconym grobem, są jego dzieła. Ktoś powie, że na koniec sam poddaję się „nałogowi żałoby”, szukając pocieszenia w apoteozie. Może to prawda. Ale nie o horacjańskim przetrwaniu w słowach i dzięki słowom mówię. Bo tym ciałem Schulza są nie słowa trwalsze niż ze spiżu, lecz papierowe kartki, zawsze gotowe się usunąć, choć przecież trwają jakimś prawem Odradka: rękopisy, rysunki, grafiki, urzędowe podania. Jak to możliwe?

Trzeba tylko zmienić punkt widzenia, oderwać się od nawykowych opozycji martwe-żywe, nieożywione-ożywione. Zaufać, że dochodzi tu do transgresji wielu transgresji w obu kierunkach. Że materia Schulzowskiego archiwum nie jest bierna, lecz w kontakcie z badaczem „nabiera ciała”, ożywia się, staje się agensem. „Tam bowiem, gdzie pojawia się kryzys «realnego» ciała, tam uwalnia się siła nekroperformansu - zapośredniczonego w materialnych resztkach oddziaływania martwego ciała. Nekroperformans nie pyta bowiem o podmiot - tu same resztki, pozostałości oddziałują na żywych. Nekroperformans dokumentuje zatem to, co w pisaniu historii umarłych zostało nieuświadomione, przeoczone lub zepchnięte na margines życia politycznego i dyskursu historycznego"66. To właśnie jest drugie ciało Schulza, materialne i historyczne, którego wcześniej nie rozpoznałem - rozczłonkowane w archiwach, licytowane na aukcjach za dziesiątki tysięcy dolarów, eksponowane w muzeach i galeriach sztuki, ukrywane przez kolekcjonerów jak relikwie.

64 Ibidem, s. 62. Podkreślenie - J.O.

65 B. Schulz, Wiosna, w: idem, Opowiadania. Wybór esejów i listów, oprac. J. Jarzębski, Wrocław 1989, S. 183.

66 D. Sajewska, Nekroperformans. Kulturowa rekonstrukcja teatru Wielkiej Wojny, Warszawa 2016, s. 38. 